\title{
Polymorphism of apolipoprotein C3 (APOC3) gene in children with HIV infection at Dr. Soetomo Hospital, Surabaya, Indonesia
}

\author{
Rika Hapsari ${ }^{1},{ }^{*}$ Dominicus Husada $^{1}$, Leny Kartina $^{1}$, Sukmawati Basuki ${ }^{2}$
}

Sri Lanka Journal of Child Health, 2021; 50(3): 424-429

\begin{abstract}
Background: Genetic factors can affect the therapeutic response to HIV infection. Apolipoprotein C3 (APOC3) polymorphism is related to metabolic disorders and hypersensitivities and affect tolerability that impacts adherence to highly active antiretroviral therapy (HAART).
\end{abstract}

Objective: To analyse the polymorphism of APOC3 gene in children with HIV infection in Dr. Soetomo Hospital, Surabaya, East Java, Indonesia.

Method: A descriptive observational study was conducted in Dr. Soetomo Hospital Surabaya from September 2019 to January 2020 in 2-13 year old children with HIV infection. APOC3 was determined by restriction fragment length polymorphism analysis. Statistical analysis was done using Fisher test. $p<0.05$ was taken as significant.

Results: Of the 24 patients, $11(45.8 \%)$ were boys and $13(54.6 \%)$ were girls. Mean age was $7.5 \pm$ 0.59 years. Twenty three $(95.8 \%)$ mothers with HIV-infected children also had positive HIV status. Sixteen $(66.7 \%)$ children had a duration of therapy less than 5 years. Mean age of child at diagnosis was $4.2 \pm 0.56$ years. Mean CD4 absolute value was $769.61 \pm 439$ cells $/ \mathrm{cu} \mathrm{mm}$, and the mean CD4\% value was $15.49 \pm 6.4 \%$. Seven $(29.2 \%)$ patients had the wild type APOC3 gene, and 17 (70.8\%) patients had the homozygous mutant APOC3 gene. There was no significant relationship between sex $(p=0.059)$, duration of therapy

\section{${ }^{1}$ Department of Child Health, Faculty of Medicine, ${ }^{2}$ Department of Parasitology, Universitas Airlangga/Dr. Soetomo Hospital Surabaya, Indonesia \\ *Correspondence: dominicushusada@yahoo.com}

https://orcid.org/ 0000-0001-9191-9546

(Received on 28 July 2020: Accepted after revision on 18 September 2020)

The authors declare that there are no conflicts of interest

Personal funding was used for the project.

Open Access Article published under the Creative

Commons Attribution CC-BY (c) (i) License
( $p=0.218)$ or history of changing therapy $(p=0.708)$ with polymorphism of APOC3 gene.

Conclusions: At Dr. Soetomo Hospital, presence of APOC3 gene polymorphism in children with HIV infection was $70.8 \%$.

DOI: http://doi.org/10.4038/sljch.v50i3.9690

(Key words: HIV Infection, APOC3, genetic)

\section{Introduction}

The genetic factors of the host can influence the response to HIV infection. Genetic polymorphisms related to HIV infection influence lipid metabolism ${ }^{1}$. Polymorphism of the Apolipoprotein C3 (APOC3) gene is associated with decreasing high density lipoprotein (HDL) and non-HDL in adult patients, and affect the total cholesterol levels in children. The polymorphisms of APOC3 gene will be associated with metabolic disorders and fat metabolism in the body. The presence of metabolic disorders is associated with high levels of lipids in the blood associated with hypersensitivity reactions to drugs so that it can lead to therapeutic failure from anti-retroviral therapy $(\mathrm{ART})^{2}$.

APOC3 gene encodes protein components of Triglyceride Rich Lipoprotein (TRL) including very low density lipoprotein (VLDL), HDL and chylomicrons. The APOC3 gene plays an important role in the metabolism of the lipoprotein that initiates the secretion of VLDL, inhibits the activity of the lipoprotein lipase enzyme, and inhibits remnant TRL catabolism ${ }^{3}$. The APOC3 gene shows a significant effect as a predictor of total cholesterol. Genetic determination with APOC3 has a large impact in the selection of therapeutic regimens and predicts the side effects of highly active antiretroviral therapy (HAART) drugs ${ }^{2}$.

Globally in 2014, of 2.6 million children aged $<15$ years infected with HIV, $88 \%$ lived in sub-Saharan Africa $^{4}$. From 2010 until 2017 in Indonesia there were 3055 children infected with HIV ${ }^{5}$. However, in Indonesia there is currently no research on genetic factors for host HIV infection in children.

\section{Objectives}

To analyse the polymorphism of APOC3 gene in children with HIV infection in Dr. Soetomo Hospital, Surabaya, East Java, Indonesia. 


\section{Method}

Study population comprised a cross section of 2-13 year old children with HIV recruited from Infection Outpatient-Clinic and hospitalized patients in Dr. Soetomo Hospital.

Amplification of the APOC3 promoter region: Genomic DNA was amplified by polymerase chain reaction (PCR) from 24 participants. The following primers were used to amplify a $238 \mathrm{bp}$ gene fragment: APOC3 5'-GGATTGAAA CCCAGAGATGGAGGTG-3' (sense) and 5'TTCACACTGGAATTTCAGGCC-3' (antisense). The PCR reaction mixture comprised a final concentration of $4 \mu \mathrm{M}$ of each primer, $200 \mu \mathrm{M}$ dNTP 4U FastStart Taq polymerase (Roche Diagnostics, Mannheim, Germany), $5 \mu \mathrm{L} 10 \times$ PCR buffer $(\mathrm{MgCl} 2,25 \mathrm{mM}), 5 \mu \mathrm{L}$ of DNA template and nuclease free water in a $50 \mu \mathrm{L}$ total reaction volume. Cycling conditions comprised an initial denaturation at $94^{\circ} \mathrm{C}$ for $3 \mathrm{~min}$, followed by 35 cycles of denaturation at $94^{\circ} \mathrm{C}$ for $2 \mathrm{~min}$, annealing at $55^{\circ} \mathrm{C}$ for $1 \mathrm{~min}$, elongation at $72^{\circ} \mathrm{C}$ for $2 \mathrm{~min}$ and a final elongation at $72^{\circ} \mathrm{C}$ for $10 \mathrm{~min}$. The resulting PCR products were resolved by electrophoresis on a $1 \%$ ethidium bromide-stained agarose gel (Invitrogen, Carlsbad, CA, USA).

Genotyping of APOC3 promoter region: Amplified DNA was purified with a Qiagen DNA purification kit (Qiagen, Valencia, CA, USA) according to the manufacturer's instructions. Genotypes of APOC3 were determined by RFLP. Restriction enzymes, FokI (restriction site: 5'GGATG(N)9^-3', Fermentas, Vilnius, Lithuania) were used for restriction sites. The digestion mixture was incubated at $37^{\circ} \mathrm{C}$ for $30 \mathrm{~min}$. Digestion products were resolved on $2 \%$ ethidium bromide-stained agarose gels (Invitrogen, Carlsbad, CA, USA).

Ethical issues: Study protocol received approval from the Dr. Soetomo Hospital Research Ethics Committee (No. 1447/EPK/VIII/2019) Study was carried out after obtaining written consent from participants or their parents after explaining to them in detail the study demographics, sample collection and sequencing DNA extraction procedures
Statistical analysis was done using Fisher exact test with a $\mathrm{p}$ value $<0.05$ being considered significant. Data was processed with SPSS software.

\section{Results}

Subject characteristics of the 24 participants are shown in Table 1 . The youngest was 2 years old and the oldest 13 years old. The 3 deaths were due to opportunistic infection and septicaemia.

Table 1: Subject characteristics $(n=24)$

\begin{tabular}{|c|c|}
\hline Characteristic & Result \\
\hline Sex-number (\%) & \\
\hline Boys & $11(45.8)$ \\
\hline Girls & $13(54.2)$ \\
\hline Mean age in years & $7.5 \pm 0.59$ \\
\hline Mean age in years when HIV was diagnosed & $4.2 \pm 0.56$ \\
\hline $\begin{array}{l}\text { Duration of therapy }- \text { number }(\%) \\
<5 \text { years } \\
\geq 5 \text { years }\end{array}$ & $\begin{array}{l}16(66.7) \\
08(33.3) \\
\end{array}$ \\
\hline Change ARV - number (\%) & \\
\hline No & $23(95.8)$ \\
\hline Yes & $01(04.2)$ \\
\hline Residence - number (\%) & \\
\hline Surabaya & $20(83.3)$ \\
\hline Other than Surabaya & $04(16.7)$ \\
\hline HIV status of mother - number (\%) & \\
\hline Positive & $23(95.8)$ \\
\hline Negative & $01(04.2)$ \\
\hline HIV status of father - number (\%) & \\
\hline Positive & $19(79.2)$ \\
\hline Negative & $05(20.8)$ \\
\hline Delivery process - number (\%) & \\
\hline Spontaneous & $22(91.7)$ \\
\hline Caesarean section & $02(08.3)$ \\
\hline Comorbid illness - number (\%) & \\
\hline None & $13(54.2)$ \\
\hline Tuberculosis & $04(16.7)$ \\
\hline Cardiomyopathy & $01(04.2)$ \\
\hline Pneumonia & $01(04.2)$ \\
\hline Thalassaemia & $02(08.3)$ \\
\hline Cerebral palsy & $01(04.2)$ \\
\hline Septicaemia & $02(08.3)$ \\
\hline Outpatient - number (\%) & $14(58.3)$ \\
\hline Hospitalized - number (\%) & $10(41.7)$ \\
\hline Outcome - number (\%) & \\
\hline Survival & $21(87.5)$ \\
\hline Death & $03(12.5)$ \\
\hline
\end{tabular}

From this study amplification was carried out on all research subjects, then continued with RFLP. The genotype for the APOC3 promoter gene of $238 \mathrm{bp}$ was cut with the FokI restriction enzyme. The results of the study appear in Figure 1 


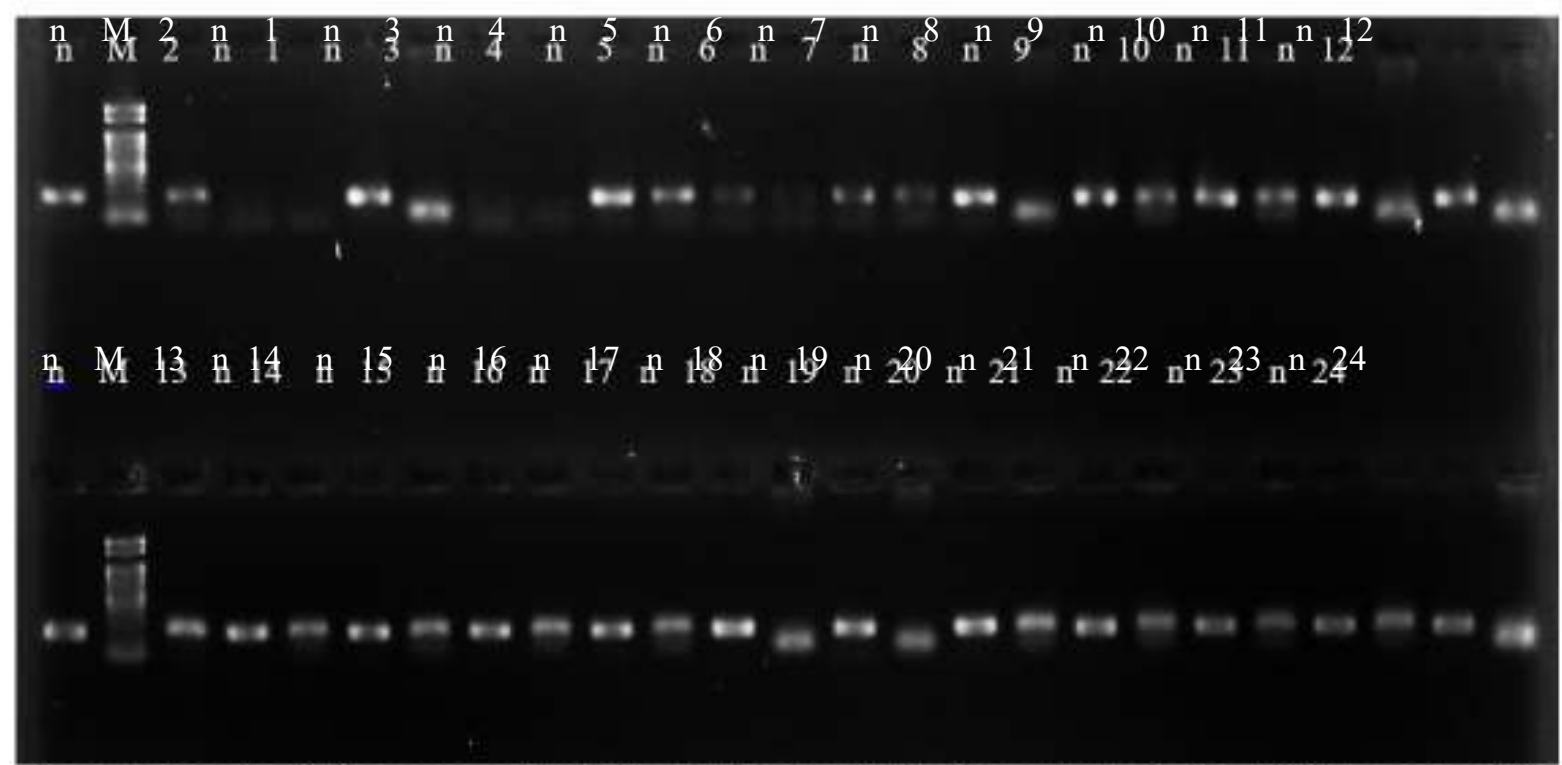

Figure 1: Results of $2 \%$ agarose gel restriction products with the FokI enzyme for the APOC3 genotype. The restriction pattern with FokI enzymes is as follows: lane $M, 100 \mathrm{bp}$ as molecular marker; lane is a variant of the CC genotype (no cut), whereas lane is a TT / wild type variant (cut with enzymes), a single band indicates no place of restriction.

From the research results we obtained various variants of the APOC3 gene, namely TT (Homozygous, wild type) and CC (Homozygous, mutant). From 24 samples, the prevalence of wild type was $7(29.2 \%)$ patients, while the prevalence of homozygous mutations was 17 (70.8\%) patients. The analysis of APOC3 in children with HIV infection is shown in Table 2.

Table 2: Analysis of APOC3 in children with HIV infection

\begin{tabular}{|l|c|c|c|}
\hline \multirow{2}{*}{ Variables } & \multicolumn{2}{|c|}{ APOC3 } & \multirow{2}{*}{$\boldsymbol{p}^{*}$} \\
\cline { 2 - 4 } & Wild Type - Number & Homozygote - Number & \multirow{2}{*}{0.059} \\
\hline Male & 1 & 10 & 0.218 \\
Female & 6 & 7 & 0.708 \\
Therapy < 5 years & 6 & 10 & 0.269 \\
\hline Nherapy $\geq 5$ years & 1 & 1 & 0.2 \\
Change ART & 7 & 1 & 0. \\
\hline Outpatient & 0 & 11 & \\
Hospitalized & 3 & 6 & \\
\hline
\end{tabular}

${ }^{*} p<0.05$ significant, Fisher exact test

\section{Discussion}

The gene polymorphisms will influence HIV infection in children. One of them is the APOC3 gene which is related to fat metabolism and distribution. The prevalence of homozygous mutations was $17(70.8 \%)$ patients. Wild type alleles show that the genes are in good condition and have a good function so that they are related to the low possibility of metabolic disorders. This study showed the low frequency of wild type alleles in HIV infected children in Surabaya. The low frequencies of wild type alleles of APOC 3 in Caucasian and Hispanic races are predominant factors in the occurrence of metabolic disorders characterized by high levels of triglycerides. The presence of metabolic disorders is associated with high blood lipid levels associated with hypersensitivity reactions to drugs and leads to the failure of therapy from $\mathrm{ART}^{4}$. Thus, genetic determination of the APOC3 gene has a large impact in the selection of therapeutic regimens and predicts the side effects of HAART drugs ${ }^{2}$.

In this study there was no gender relationship with the polymorphism of the APOC3 gene. The mechanism by which sex hormones influence the APOC3 gene on lipid metabolism is still unclear. According to a meta-analysis study by Cheng $\mathrm{S}$, et $a l^{6}$, triglyceride concentrations in women carrying variants of the APOC3 SstI allele were higher than in men. There was a relationship between the polymorphism of the APOC3 gene and triglyceride levels, but there was no gender difference in the expression of the APOC3 gene ${ }^{6}$. According to the 
study by Ruel TD, et $a l^{7}$, the existence of gender differences affects the immunological status of HIV infected children. This is due to the immunomodulatory effects of female sex hormones that influence the expression of CCR5 via CD4 and produce several cytokines. In addition, female sex hormones and fluctuations during the ovulation cycle will modulate innate and adaptive immune responses. Then it will affect the replication rate of the HIV virus?

The polymorphisms on the APOC3 gene is associated with metabolic disorders and fat metabolism in the body. The presence of metabolic disorders is related to the high lipid levels in the blood associated with hypersensitivity reactions to drugs so that it can lead to therapeutic failure from $\mathrm{ART}^{2}$. Genetic determination of the APOC3 gene has a large impact in the selection of therapeutic regimens and predicts the failure of HAART drugs in children with HIV infection in Africa ${ }^{8,9}$. Highly active ART brings about significant improvement, improving the quality of life of HIV children ${ }^{10}$. The influence of race / ethnicity, APOC3 genotype, and exposure to protease inhibitors are significant predictors of HDL cholesterol levels in HIV infection. The results of the study showed low triglyceride levels and high HDL cholesterol levels in black/non-Hispanic races compared to Caucasian and Hispanic races ${ }^{11}$.

The presence of APOC3 gene polymorphisms will cause overexpression of the APOC 3 gene, thus increasing the synthesis of plasma triglycerides and the accumulation of VLDL and insulin secretion through the mechanism of calcium channel intervention in pancreatic beta cells, excess insulin synthesis causing insulin resistance ${ }^{12}$. A study by Tarr PE, et $a l^{13}$ examining APOE and APOC3 genotyping in adults with HIV infection in Switzerland showed that people with HIV infection who received ritonavir therapy had a risk of developing hypertriglyceridaemia. The study showed that variant alleles of APOE and APOC3 contributed to the lipid profile of HIV patients. The interaction between genotypes and ARVs will cause hyperlipidaemia. This study showed the presence of polymorphisms associated with hyperlipidaemia in the European continent ${ }^{13}$.

The mechanism of metabolic changes associated with the administration of antiretroviral drugs is still being debated. Protease inhibitors can initiate adipocyte differentiation apoptosis. In addition, protease inhibitors inhibit pre-adipocyte differentiation even if only in vitro. The existence of these mechanisms contribute to lipoatrophy and the release of fatty acids which then reach the liver. This causes the liver to synthesize triglycerides and more VLDL ${ }^{14}$. The use of protease inhibitors will disrupt the normal regulation of the APOC 3 gene, causing over-expression of the APOC 3 gene and affecting the transcription process of the APOC3 gene. Over-expression of the APOC3 gene will directly affect insulin production in pancreatic beta cells. Insulin will inhibit the work of the APOC3 gene so that the down regulation of APOC3 gene expression is down. The APOC3 gene polymorphisms will disrupt the down regulation process $^{11}$.

The presence of polymorphisms in the APOC3 promoter gene will influence the regulation of APOC3 expression. Evaluation of allele distribution of promoter variations in certain population races is very important to know the existence of variations in APOC 3 activity. Studies in Kuwait show that the high frequency of APOC3 polymorphism is $49.5 \%$. This figure is higher than in the Caucasian population at $42 \%$. Analyzing the frequency of polymorphisms in different ethnic populations showed a high frequency in AfricanAmerican ethnicity (71.2\%), Hispanic (38.9\%) and European (36.6\%). The different frequency of alleles in different ethnic groups shows that ethnic differences affect the expression of APOC 3 genes that are different in each ethnicity ${ }^{15}$.

A study by Van Den Hof $\mathrm{M}$, et $a l^{16}$ in the Netherlands, shows that differences in APOC genotype contribute to differences in LDL levels and also lipoprotein levels in children with perinatal HIV infection compared to controls ${ }^{16}$. The presence of APOC3 gene polymorphisms will affect serum triglyceride levels in HIV patient populations in Thailand but unfortunately research on the Asian Continent is only limited to adults ${ }^{17}$.

The strength of this study is that this is the first study in Indonesia and even in Southeast Asia which examined the presence of gene polymorphisms from host factors for HIV infection in children. The weakness of this study is the small number of research samples so that further research needs to be done with a larger sample size.

\section{Conclusions}

The presence of APOC3 gene polymorphism in children with HIV infection is $70.8 \%$.

\section{Acknowledgements}

The authors thank the study participants. We especially thank Prof. Haruki Uemura from Japan for support during this study.

\section{References}

1. Drake AL, Wagner A, Richardson B, John-Stewart G. Incident HIV during pregnancy and postpartum and risk of 
mother-to-child HIV transmission: A systematic review and meta-analysis. Plos Medicine 2014; 11(2): e1001608.

https://doi.org/10.1371/journal.pmed.1001 608

PMid: 24586123 PMCid: PMC3934828

2. Masebe T, Bessong PO, Ndip RN, Meyer D. Genetic variants of APOC3 Promoter and HLA-B genes in an HIV infected cohort in Northern South Africa: A pilot study. International Journal of Molecular Sciences 2014;199:11403-15.

https://doi.org/10.3390/ijms150711403

PMid: 24972136 PMCid: PMC4139789

3. Norata GD, Tsimikas S, Pirillo A, Catapano AL. Apolipoprotein C-III: From pathophysiology to pharmacology. Trends in Pharmacological Sciences 2015; 36(10):675-87.

https://doi.org/10.1016/j.tips.2015.07.001

PMid: 26435212

4. Drouin O, Bartlett G, Nguyen Q, Low A, Gavriilidis $\mathrm{G}$, Easterbrook $\mathrm{P}$, et al. Incidence and prevalence of opportunistic and other infections and the impact of antiretroviral therapy among HIV-infected children in low- and middle-income countries: A systematic review and metaanalysis. Cliinical Infectious Diseases 2016; 62(12): 1586-94.

https://doi.org/10.1093/cid/ciw139

PMid: 27001796 PMCid: PMC4885647

5. Ministry of Health of Indonesia. Information and Data Centre of Ministry of Health of Indonesia. Ministry of Health of Indonesia. 2018.

6. Cheng S, Pang B, Gu C, Sun S-P, An C, Zhang Z-P, et al. Association between apolipoprotein C3 gene promoter polymorphisms and fasting triglyceride level: A meta-analysis. Frontiers in Laboratory Medicine 2017; 1(3): 151-7. https://doi.org/10.1016/j.flm.2017.10.002

7. Ruel TD, Zanoni BC, Ssewanyana I, Cao H, Havlir D V., Kamya M, et al. Sex differences in HIV RNA Level and CD4 cell percentage during childhood. Clinical Infectious Diseases 2011; 53(6): 592-9. https://doi.org/10.1093/cid/cir484 PMid: 21840929 PMCid: PMC3160805

8. Rocco CA, Mecikovsky D, Aulicino P, Bologna R, Sen L, Mangano A.
Hypercholesterolaemia is associated with the Apolipoprotein C-III ( APOC3 ) genotype in children receiving HAART: An eight-year retrospective study. PLOS One 2012; 7(7): e39678

https://doi.org/10.1371/journal.pone.0039 678

PMid: 22848358 PMCid: PMC3405089

9. Tshamala HK, Aketi L, Tshibassu PM, Ekila MB, Mafuta EM, Kayembe PK, et al. The lipodystrophy syndrome in HIVinfected children under antiretroviral therapy: A first report from the Central Africa. International Journal of Pediatrics 2019; 2019:1-6.

https://doi.org/10.1155/2019/7013758

PMid: 30941184 PMCid: PMC6420969

10. Abers MS, Shandera WX, Kass JS. Neurological and psychiatric adverse effects of antiretroviral drugs. CNS Drugs 2014; 28(2):131-45. https://doi.org/10.1007/s40263-013-01324 PMid: 24362768

11. Foulkes AS, Wohl DA, Frank I, Puleo E, Restine S, Wolfe ML, et al. Associations among race/ethnicity, apoC-III genotypes, and lipids in HIV-1-infected individuals on antiretroviral therapy. PLoS Medicine 2006; 3(3): 337-47. https://doi.org/10.1371/journal.pmed.0030 052

PMid: 16417409 PMCid: PMC1334223

12. Gangabadage CS, Zdunek J, Tessari M, Nilsson S, Olivecrona G, Wijmenga SS. Structure and dynamics of human apolipoprotein CIII. Journal of Biological Chemistry 2008; 283(25): 17416-27. https://doi.org/10.1074/jbc.M800756200 PMid: 18408013

13. Tarr PE, Taffé P, Bleiber G, Furrer H, Rotger $\mathrm{M}$, et al. Modeling the influence of APOC3, APOE, and TNF Polymorphisms on the risk of antiretroviral therapy-associated lipid disorders. Journal of Infectious Diseases 2005; 191(9): 1419-26.

https://doi.org/10.1086/429295

PMid: 15809899

14. Fauvel J, Bonnet E, Ruidavets JB, Ferrières $\mathrm{J}$, Toffoletti A, Massip $\mathrm{P}$, et al. An interaction between apo C-III variants and protease inhibitors contributes to high 
triglyceride/low HDL levels in treated HIV patients. Aids 2001; 15(18): 2397406.

https://doi.org/10.1097/000020302001120 70-00007

PMid: 11740190

15. Malalla ZH, Al-Serri AE, Alaskar HM, Al-Kandari WY, Al-Bustan SA. Sequence analysis and variant identification at the APOC3 gene locus indicates association of rs5218 with BMI in a sample of Kuwaiti's. Lipids in Health and Disease 2019; 18(1): 1-13.

https://doi.org/10.1186/s12944-019-11656

PMid: 31856839 PMCid: PMC6921598
16. Van Den Hof M, Haneveld MJK, Blokhuis C, Scherpbier HJ, Jansen HPG, Kootstra NA, et al. Elevated lipoprotein(a) in perinatally HIV-Infected children compared with healthy ethnicity-matched controls. Open Forum Infectious Diseases 2019; 6(9): 1-8.

17. Likanonsakul S, Rattanatham T, Feangvad S, Uttayamakul S, Prasithsirikul W, Srisopha $\mathrm{S}$, et al. Polymorphisms in fas gene is associated with HIV-related lipoatrophy in thai patients. AIDS Research and Human Retroviruses 2013; 29(1): 142-50.

https://doi.org/10.1089/aid.2012.0114

PMid: 22775001 PMCid: PMC3537319 